Muhamad Nasrulloh, Achendri M. Kurniawan. 2018. Perbandingan variasi agregat halus yang berasal dari gunung kelud, kali putih, dan sungai brantas terhadap kuat tekan beton. Jurnal Qua Teknika, (2018), 8 (1) : 32-41

\title{
PERBANDINGAN VARIASI AGREGAT HALUS YANG BERASAL DARI GUNUNG KELUD, KALI PUTIH, DAN SUNGAI BRANTAS TERHADAP KUAT TEKAN BETON
}

\author{
Muhamad Nasrulloh, Achendri M. Kurniawan \\ Program Studi Teknik Sipil, Fakultas Teknik, Universitas Islam Balitar Blitar \\ Jl. Majapahit No. 4 Blitar Jawa Timur \\ Email : Nasrul.254stw@gmail.com
}

\begin{abstract}
Concrete is a building material widely used in construction projects. In principle to create concrete with very good quality by the quality of its constituents of fine aggregate (sand), coarse aggregate, semen, and air, and the way it works. The fine aggregate (sand) as the base material for concrete manufacture is required in determining the quality of the concrete, since the aggregate is a filler bound by cement and water into a solid mass, the quality of fine aggregate luminaire (sand) directly affects the quality of the concrete. The fine aggregate (sand) used in this study came from 3 samples in Blitar area, ie 1 sample from Kelud mountain, 2 samples from Kali Putih, and 3 samples from Brantas River. Location of research at the Laboratory Structural Civil Engineering University Tribhuwana Tunggadewi Malang. The method used in this study using laboratory experiments and guided on SNI 03-06912000. After a fine aggregate study of 3 samples in Bitarit obtained the average compressive strength test, samples of 1 fine aggregate (sand) of Kelud mount recorded average of concrete compressive strength of 7,802 Mpa (highest), sample 2 of fine aggregate ( sand) of Kali Putih resulted in average concrete strength test of $3.208 \mathrm{Mpa}$ (lowest), and a sample of 3 fine aggregate (sand) of Brantas river yielded average concrete strength test of $3,272 \mathrm{MPa}$
\end{abstract}

Kata kunci : Aggregate, Kali Putih, Kelud, Brantas

\begin{abstract}
ABSTRAK
Beton merupakan material bahan bangunan yang banyak dipergunakan dalam pelaksanaan proyek konstruksi. Pada prinsipnya untuk mendapatkan beton dengan kualitas yang baik sangat dipengaruhi oleh kualitas dari bahan - bahan penyusunnya yaitu agregat halus (pasir), agregat kasar, semen, dan air, serta cara pengerjaannya. Agregat halus (pasir) sebagai bahan dasar untuk pembuatan beton memegang peranan penting dalam menentukan mutu beton, karena agregat merupakan bahan pengisi yang diikat oleh semen dan air menjadi massa padat, sehingga kualitas agregat halus (pasir) mempengaruhi langsung terhadap mutu beton. Agregat halus (pasir) yang dibahas pada penelitian ini berasal dari 3 sampel di wilayah Blitar, yaitu sample 1 dari gunung Kelud, sampel 2 dari kali Putih, dan sampel 3 dari sungai Brantas. Lokasi penelitian di Laboratorium Struktur Teknik Sipil Universitas Tribhuwana Tunggadewi Malang. Metode yang digunakan dalam penelitian ini menggunakan eksperimen laboratorium dan berpanduan pada SNI 03-06912000. Setelah dilakukan penelitian agregat halus dari 3 sampel diBlitar mendapatkan hasil uji kuat tekan rata -rata yaitu, sample 1 agregat halus (pasir) gunung Kelud menghasilkan rata - rata uji kuat tekan beton sebesar 7,802 Mpa (tertinggi), sample 2 agregat halus (pasir) Kali Putih menghasilkan rata rata uji kuat tekan beton sebesar 3,208 Mpa (terendah), dan sample 3 agregat halus (pasir) sungai Brantas menghasilkan rata - rata uji kuat tekan beton sebesar 3,272 Mpa
\end{abstract}

Kata kunci : Agregat, Kali Putih, Kelud, Brantas

Pada bulan Februari 2014 telah terjadi peristiwa erupsi gunung Kelud. Dengan peristiwa tersebut, dapat diambil banyak hikmahnya, salah satunya yaitu sebagai sumber agregat halus (pasir), yang dimana jumlah agregat halus (pasir) sangatlah banyak, dengan begitu dapat dimanfaatkan oleh masyarakat sekitar sebagai mata pencaharian mereka. Pada penelitian ini membahas tentang agregat halus (pasir) dari tiga (3) wilayah berbeda di Blitar, yaitu dari gunung Kelud, Kali Putih, dan sungai Brantas. yang dimana agregat halus (pasir) dibawa oleh arus air sungai 
Muhamad Nasrulloh, Achendri M. Kurniawan. 2018. Perbandingan variasi agregat halus yang berasal dari gunung kelud, kali putih, dan sungai brantas terhadap kuat tekan beton. Jurnal Qua Teknika, (2018), 8 (1) : 32-41

mulai dari hulu hingga ke hilir.

Agregat halus (pasir) dari gunung Kelud, banyak sekali jenis pasir didaerah (atas) gunung Kelud, yang dimana disinilah sumber agregat halus berasal, yang kemudian akan dibawa kebawah oleh arus air (sungai). Disana juga ada pembangunan kembali paska terjadi erupsi dan material agregat halus (pasir) berasal sekitar lokasi pembangunan atau dari gunung Kelud sendiri.

Agregat halus (pasir) dari Kali Putih, di tempat inilah banyak penambangan pasir dilakukan, penambangan masih dilakukan dengan cara manual, penambangnya pun juga dari berbagai wilayah, bukan hanya warga penduduk daerah Kali Putih. Banyak yang mengatakan bahwa pasir dari Kali Putih juga bagus untuk pembangunan, bahkan juga penambang menerima banyak order dari luar wilayah Blitar.

Agregat halus (pasir) dari sungai Brantas, selain dari gunung Kelud dan Kali Putih, banyak juga penambang dijumpai di sungai Brantas. Penambangan di sungai Brantas didukung dengan akses jalannya mudah ketimbang dari kedua tempat yang disebutkan sebelumnya. Pengambilan Agregat halus (pasir) ada yang menggunakan bantuan mesin penyedot pasir dan secara manual

Penggunaan agregat halus (pasir) dan juga pemilihan permukaan agregat halus (pasir) akan berpengaruh terhadap kekuatan beton atau kekuatan ikat dari campuran material penyusun beton, untuk itu perlu diadakannya penelitian terhadap penggunaan agregat halus (pasir) yang umum digunakan. Hal tersebut dilakukan sampai sejauh mana pengaruh karakteristik agregat halus (pasir) pada campuran beton terhadap karakteristik dan mutu suatu beton dan dapat memberikan penjelasan agregat halus (pasir) yang seperti apa yang baik untuk dipergunakan dalam pembuatan beton normal.

Pada penelitian ini, penulis mengambil skripsi dengan judul "Perbandingan Variasi Agregat Halus YangBerasal Dari Gunung Kelud, Kali Putih, Dan Sungai Brantas Terhadap Kuat Tekan Beton" denganbahan agregat halus (pasir) dari 3 (tiga) sampel, sampel tersebut berasal dari gunung Kelud, Kali Putih dan sungai Brantas. Alasan penelitian ini dikarenanakan belum ada yang meneliti tentang Agregat halus (pasir) dari ketiga wilayah diBlitar dan juga untuk mengetahui karakteristik dan pengaruh ketiga sampel campuran agregat halus (pasir) yang terhadap kuat tekan beton.

\section{Tujuan Penelitian}

Adapun beberapa tujuan dari penelitian ini adalah sebagai berikut :

1. Mengetahui perbedaan karakteristik Agregat halus (pasir) dari 3 lokasi berbeda di Blitar terhadap kuat tekan beton

2. Mengetahui pengaruh Agregat halus (pasir) terhadap kuat tekan beton

\section{Manfaat Penelitian}

Penelitian ini diharapkan akan memberikan manfaat baik secara teoritis dan praktis. Secara teoritis penelitian ini akan memberikan pengetahuan dan pemahaman lebih mengenai penggunaan material agregat halus terhadap karakteristik beton baik dari kelebihan dan kekurangannya, sehingga perkembangan teknologi beton bisa lebih ditingkatkan mutu dan kualitasnya.

\section{Definisi Beton}

Beton adalah campuran antara semen portland atau semen hidrolik yang lain, agregat halus, agregat kasar dan air, dengan atau tanpa bahan tambahan yang membentuk masa padat (SNI 032847-2002,Pasal 3.12). Sifat utama dari beton, yaitu sangat kuat terhadap beban tekan, tetapi juga bersifat getas / mudah patah atau rusak terhadap beban tarik. Dalam perhitungan struktur, kuat tarik beton ini biasanya diabaikan. (Rukman Pattinjjo, 13Agustus 2017, 11:02)

Karena hidrasi semen oleh air, adukan tersebut akan mengeras/membatu dan memiliki kekerasan dan kekuatan yang dapat dimanfaatkan untuk berbagai tujuan. Nilai kekuatan serta daya tahan (durability) beton dipengaruhi antara lain oleh perbandingan dan mutu bahan penyusun beton, metode pelaksanaan pengecoran, pelaksanaan finishing, temperature dan kondisi perawatan pengerasannya. Ditinjau dari berat isi beton, beton normal adalah beton yang mempunyai berat isi 
Muhamad Nasrulloh, Achendri M. Kurniawan. 2018. Perbandingan variasi agregat halus yang berasal dari gunung kelud, kali putih, dan sungai brantas terhadap kuat tekan beton. Jurnal Qua Teknika, (2018), 8 (1) : 32-41

$2200-2500 \mathrm{~kg} / \mathrm{m} 3$ yang menggunakan agregat alam yang pecah atau tanpa dipecah yang tidak menggunakan bahan tambahan (SNI $03-2847-2002$ ). Kuat tekan beton normal berkisar antara n28-60 MPa pada umur beton 28 hari. Penggunaan beton mutu normal banyak dipakai untuk konstruksikonstruksi sederhana seperti perumahan dan bangunan gedung yang tidak terlalu tinggi dimana kebutuhan kuat tekan tidak terlalu besar. Kelemahan dalam penggunaan beton mutu normal yaitu kekuatan yang kecil dan sifat khusus yang terbatas. Sifat sifat khusus yang diinginkan antara lain tahan terhadap agresi kimiawi, kedap air, tahan terhadap pengaruh lingkungan dimana beton tersebut dipakai. Adapun bahan pembentuk beton adalah sebagi berikut :

\section{Semen Portland (PC)}

Semen adalah bahan pengikat hidrolis yang terbuat dari penggilingan halus (klingker) dan gips, bila dicampur air didiamkan akan mengikat, mengeras, membatu dan direndam dalam air tidak larut. Bahan baku pembuat semen adalah bahan-bahan yang mengandung trikalsium silikat (C3S) atau 3CaO.SiO2, dikalsium silikat (C2S) atau 2CaO.SiO2, trikalsium aluminat (C2A) atau 3CaO.Al3, tetrakalsium (C2AF) atau 4CaO.Al2O3.Fe2O2

\section{Agregat (Pasir dan Kerikil)}

Agregat adalah butiran mineral alami yang berfungsi sebagai bahan pengisi dalam campuran mortar atau beton. Kira - kira $70 \%$ volume mortar atau beton diisi oleh agregat. Agregat sangat berpengaruh terhadap sifat - sifat mortar atau beton, sehingga pemiligan agregat merupakam suatu bagian penting dalam pembuatan mortar atau beton. Dari segi ekonomis lebih menguntungkan jika digunakan campuran beton dengan sebanyak mungkin bahan pengisi dan sedikit mungkin jumlah semen. Namun keuntungan dari segi ekonomis harus diseimbangkan dengan kinerja beton baik dalam keadaan segar maupun setelah mengeras.

Agregat harus mempunyai bentuk yang baik (bulat dan mendekati kubus), bersih, keras, kuat dan gradasinya baik dan agregat harus pula mempunyai kestabilan kimiawi dan dalam hal - hal tertentu harus tahan aus dan tahan cuaca

Air

Air diperlukan pada pembentukan semen yang berpengaruh terhadap sifat kemudahan pengerjaan adukan beton (workability), kekuatan susut dan keawetan beton, air yang diperlukan untuk bereaksi dengan semen hanya sekitar $25 \%$ dari berat semen saja, namun dalam kenyataannya nilai faktor air semen yang dipakai sulit jika kurang dari 0,35. Kelebihan air dari jumlah yang dibutuhkan dipakai sebagai pelumas. Tambahan air ini tidak boleh terlalu banyak karena kekuatan beton menjadi rendah dan beton menjadi keropos. Kelebihan air ini dituang (bleeding) yang kemudian menjadi buih dan terbentuk suatu selaput tipis (laitance). Selaput tipis ini akan mengurangi lekatan antara lapis - lapis beton dan merupakan bidang sambung yang lemah (Tjokrodimuljo,1996) (https://hadaiyatullailliah.wordpress.com/2016/04/02/bahan-penyusu-beton) 14.29. 9 November 2017

\section{Kuat Tekan Beton}

Kuat tekan beton didapatkan dengan menggunakan mesin uji dengan cara memberikan beban tekan bertingkat dengan kecepatan peningkatan beban tertentu atas benda uji silinder sampai hancur. Kuat tekan masing-masing benda uji ditentukan oleh tegangantegangan tekan tertinggi $\left(f^{\prime} c\right)$ yang dicapai benda uji pada umur yang telah ditentukan, yaitu dengan umur 3 hari, 7 hari, 14 hari, dan 28 hari. Beban tekan selama percobaan yang dinyatakan dengan satuan N/mm2 atau MPa (Mega Pascal) Nilai uji tekan yang diperoleh dari setiap benda uji akan sering berbeda cukup jauh karena beton merupakan material heterogen, yang kekuatannya dipengaruhi oleh proporsi campuran, bentuk dan ukuran, komposisi material pembentuk beton, perbandingan air semen dan kepadatan, umur beton, jenis dan jumlah semen, sifat agregat, kecepatan pembebanan serta kondisi pada saat pengujian. Berdasarkan beban runtuh yang dapat diterima oleh benda uji, maka nilai kuat tekan beton dihitung berdasarkan besarnya tekanan dibagi dengan luas permukaan tekanan :

$$
{f^{\prime}}^{\prime}=\frac{P_{\max }}{A}
$$

Dengan : 


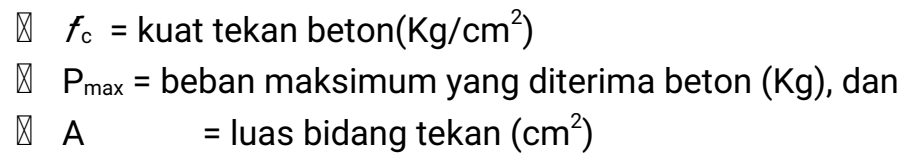

\section{METODE PENELITIAN}

Pada pelaksanaan penelitian ini menggunakan metode SNI 03-0691-2000 untuk perencanaan komposisi beton, adapun tahapan dalam metode pelaksanaan penelitian

digambarkan dalam gambar bagan alir penelitain sebagai berikut :

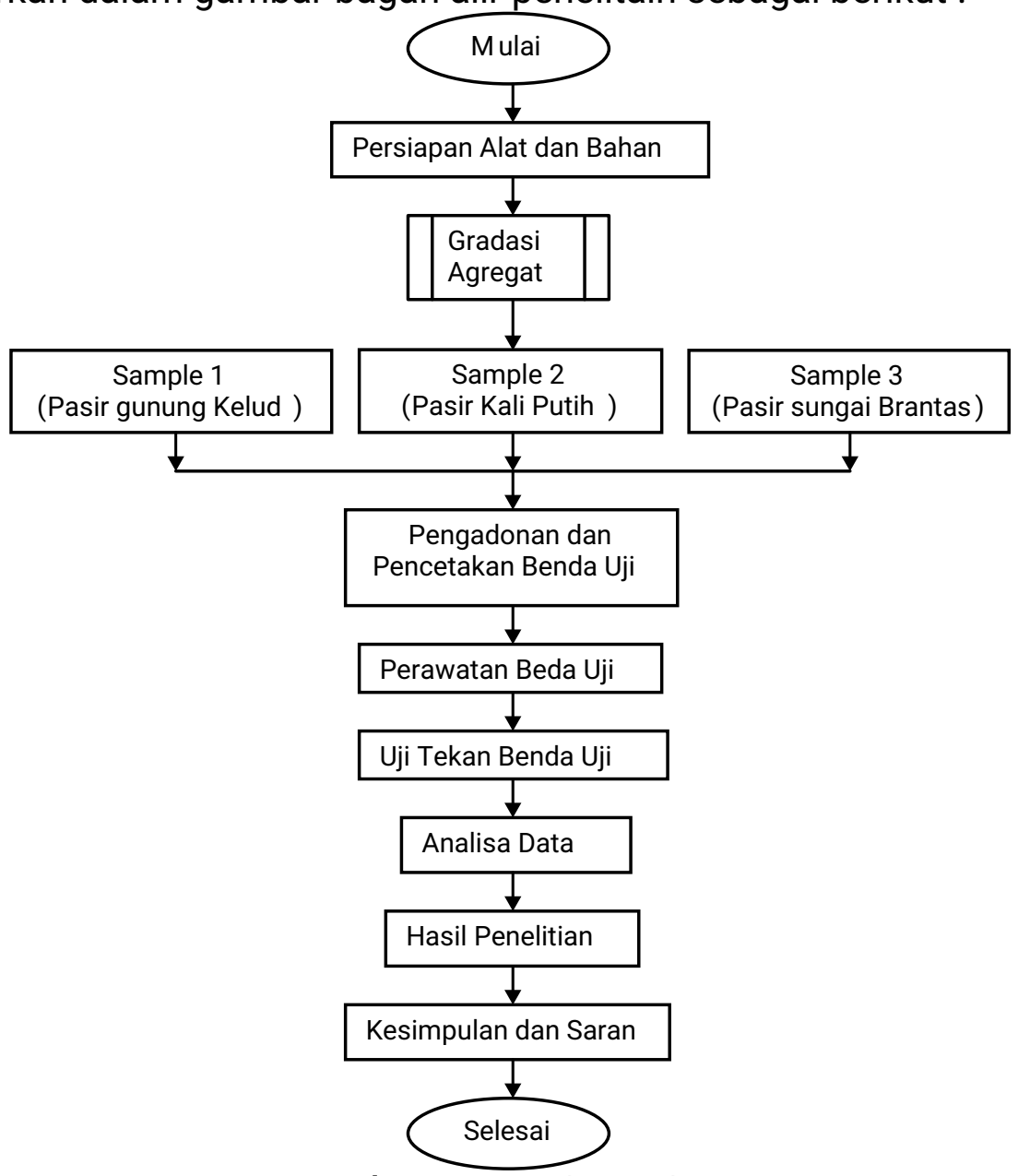

Gambar 1 Bagan alir penelitian

\section{Persiapan alat dan bahan \\ Persiapan alat}

Peralatan yang digunakan dalam penelitian ini yaitu cetakan berbentuk silinder dengan ukuran diameter $15 \mathrm{~cm}$ dan tinggi $30 \mathrm{~cm}$, mesin uji kuat tekan beton, mesin getar ayakan, oven, timbangan (timbangan digital dengan ketelitaian 0,1 gram dan timbangan duduk ), cetok, ayakan pasir dan kerikil, piknometer, mistar, cetakan uji slump, dan alat bantu lainnya pada saat pencetakan benda uji.

\section{Persiapan bahan}

1. Agregat Halus Gunung Kelud

2. Agregat halus sungai Putih (Kali Putih) 
3. Agregat halus sungai Brantas

\section{Pengujian Sifat fisik Material}

a) Pemeriksaan gradasi dari agregat kasar dan agregat halus.

b) Pemeriksaan kadar air dari agregat kasar dan agregat halus.

c) Pemeriksaan berat jenis dan penyerapan air dari agregat kasar dan agregat halus.

d) Pemeriksaan berat volume / isi agregat halus dan agregat kasar.

\section{Pembuatan benda uji}

a) Kebutuhan material beton berdasarkan dari perencanaan perhitungan (mix design)

b) Pembuatan benda uji yang berbentuk silinder, $\phi=15 \mathrm{~cm}, \mathrm{t}=30 \mathrm{~cm}$.

c) pemeriksaan nilai slump yang digunakan yaitu dengan nilai slump $60 \mathrm{~mm}-180 \mathrm{~mm}$

d) Pemeriksaan kuat tekan pada umur 7 hari. Dicetak dari setiap sampelnya sebanyak 3 buah benda uji, sehingga total benda uji sebanyak 9 buah benda uji.

Tabel 1 Variasi agregat halus dan Jumlah Benda Uji

\begin{tabular}{|c|l|c|c|}
\hline $\begin{array}{c}\text { No } \\
\text { Sampe } \\
\text { I }\end{array}$ & \multicolumn{1}{|c|}{ Nama Benda Uji } & $\begin{array}{c}\text { Kode } \\
\text { Benda Uji }\end{array}$ & $\begin{array}{c}\text { Jumlah } \\
\text { Benda } \\
\text { Uji }\end{array}$ \\
\hline 1 & $\begin{array}{l}\text { Campuran agregat halus gunung } \\
\text { Kelud }\end{array}$ & $\mathrm{A}$ & 3 \\
\hline 2 & Campuran agregat halus Kali Putih & $\mathrm{B}$ & 3 \\
\hline 3 & $\begin{array}{l}\text { Campuran agregat halus sungai } \\
\text { Brantas }\end{array}$ & $\mathrm{C}$ & 3 \\
\hline
\end{tabular}

\section{HASIL DAN PEMBAHASAN}

\section{Analisa gradasi agregat kasar}

Pada penelitian ini, material ageregat kasar (kerikil) sama untuk semua campuran beton dari ketiga (3) sampel yang telah dilakukan mix design. Agregat kasar (kerikil) berasal dari yang telah disediakan laboratorium Struktur Teknik Sipil Universitas tribhuwana Tunggadewi Malang $\Sigma \%$ yang tertahan ayakan no $3 / 4+3 / 8$ sampai 100 sebesar 849.59

Modulus halus kerikil

$$
\begin{aligned}
& =\frac{\sum \% \text { yang tertahan ayakan no } 3 / 4+\frac{3}{8} \text { sampai no } 100}{100} \\
& =\frac{849.59}{100}=8.4959
\end{aligned}
$$

Agregat kasar masuk zona 4 


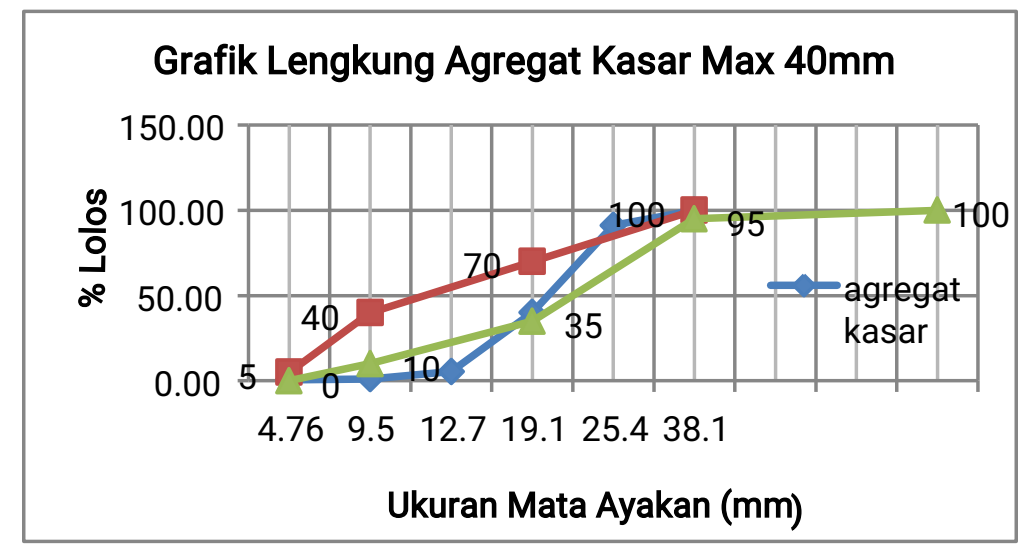

Grafik 1 Lengkung agregakasar zona 4

Kadar air agregat kasar rata - rata $2.82 \%$

\section{Berat jenis dan penyerapan agregat kasar}

$\triangle$ Berat Jenis Curah sebesar 2.632 gram

$\triangle$ Berat Jenis Kering Permukaan Jenuh sebesar 2.737

$\triangle$ Berat Jenis Semu sebesar 2.941 gram

$\triangle$ Penyerapan (\%)sebesar 4.000 gram

\section{Analisa gradasi agregat halus}

\section{Analisa gradasi agregat halus dari gunung Kelud}

$\Sigma \%$ yang tertahan ayakan no $3 / 8$ sampai 100 sebesar 178.255

Modulus halus pasir $=\frac{\sum \% \text { yang tertahan ayakan no 3/8 sampai no } 100}{100}$

$$
=\frac{178.255}{100}=1.78255
$$

Dilihat dari grafik, maka masuk zona 2 


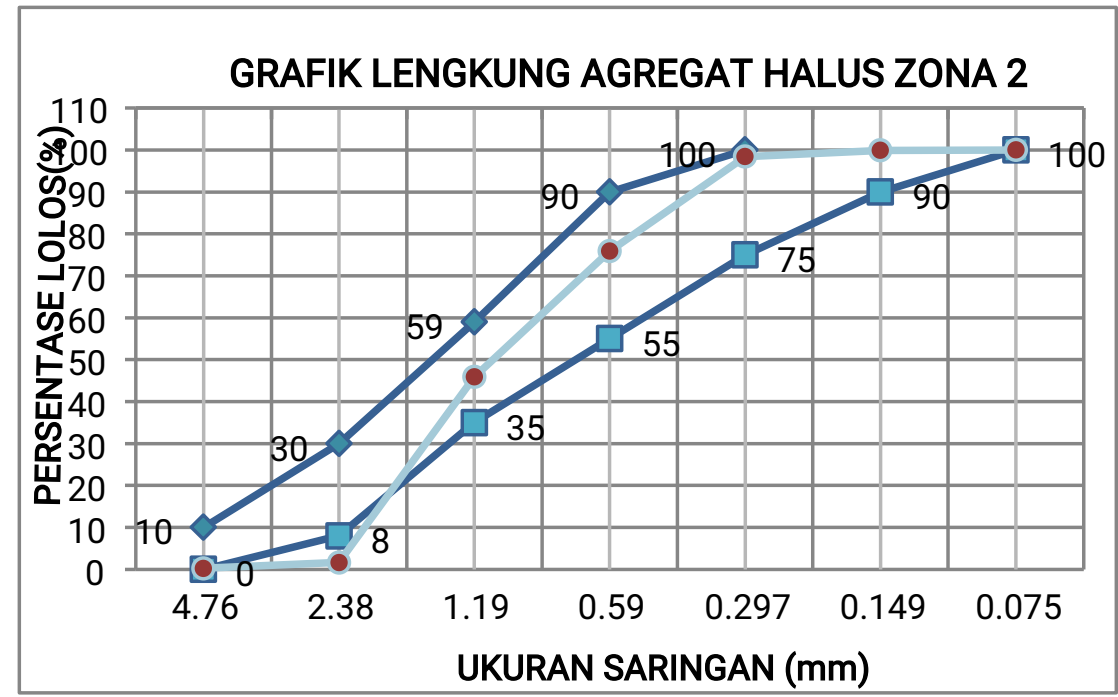

Grafik 2 Lengkung agregat halus zona 2

Kadar air agregat halus rata - rata $0.77 \%$

\section{Berat jenis dan penyerapan agregat halus}

a) Berat Jenis Curah sebesar 6.642 gram

b) Berat Jenis Kering Permukaan Jenuh sebesar 6.2.753

c)Berat Jenis Semu sebesar 2.973 gram

d) Penyerapan (\%)sebesar 4.210 gram

\section{Kebutuhan Bahan (mix design)}

Berdasarkan dari perhitungan kebutuhan bahan material (mix design) memerlukan :
a)Semen
$: 5.78 \mathrm{~kg}$
b)Air
$: 3.91 \mathrm{lt}$
c)Agregat halus
$: 11.07 \mathrm{~kg}$
d)Agregat kasar
$: 23 \mathrm{~kg}$

\section{Analisa gradasi agregat halus dari Kali Putih}

$\Sigma \%$ yang tertahan ayakan no $3 / 8$ sampai 100 sebesar 284.139

Modulus halus pasir

$$
\begin{gathered}
=\frac{\sum \% \text { yang tertahan ayakan no } \frac{3}{8} \text { sampai no } 100}{100} \\
=\frac{284.139}{100}=2.84139
\end{gathered}
$$

Dilihat dari grafik, maka masuk zona 1 


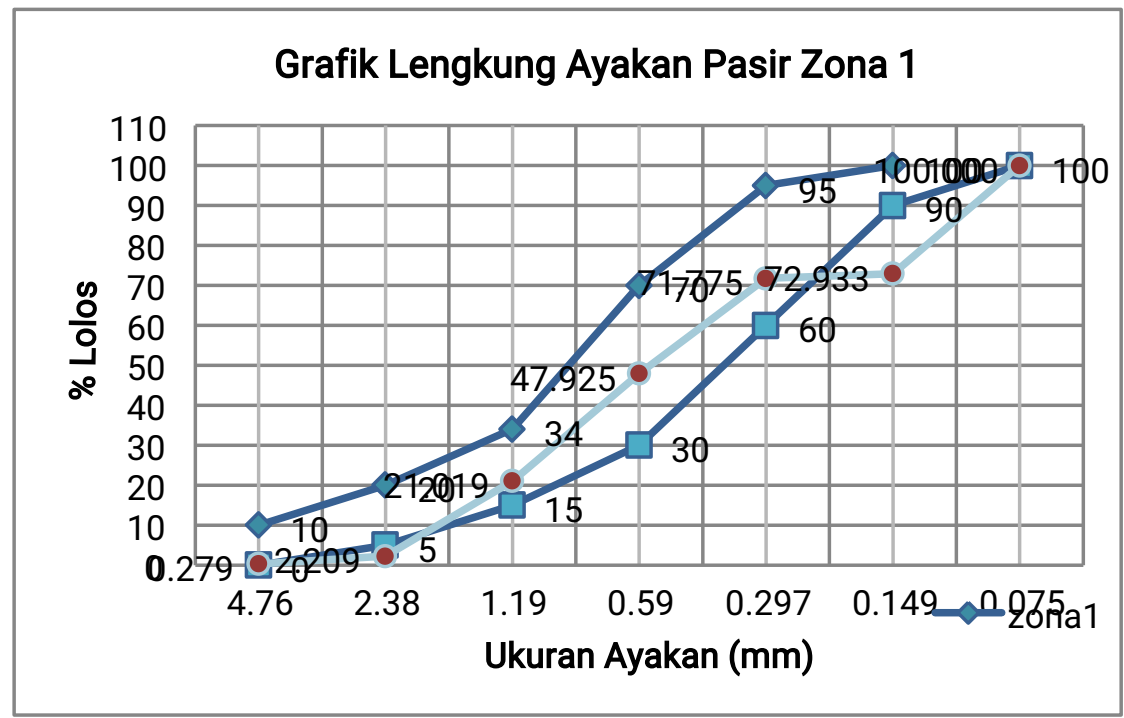

Grafik 3 Lengkung agregat halus zona 1

Kadar air agregat halus rata - rata $4.43 \%$

\section{Berat jenis dan penyerapan agregat halus}

a) Berat Jenis Curah sebesar 2.705 gram

b) Berat Jenis Kering Permukaan Jenuh sebesar 2.818

c)Berat Jenis Semu sebesar 3.052 gram

d) Penyerapan (\%)sebesar 4.210 gram

\section{Kebutuhan Bahan (mix design)}

Berdasarkan dari perhitungan kebutuhan bahan material (mix design) memerlukan :
a)Semen
$: 5.78 \mathrm{~kg}$
b)Air
$: 3.46 \mathrm{lt}$
c)Agregat halus
$: 14.01 \mathrm{~kg}$
d)Agregat kasar
: $20.72 \mathrm{~kg}$

\section{Analisa gradasi agregat halus dari sungai Brantas}

$\sum \%$ yang tertahan ayakan no $3 / 8$ sampai 100 sebesar 177.673

Modulus halus pasir

$$
\begin{gathered}
=\frac{\sum \% \text { yang tertahan ayakan no } 3 / 8 \text { sampai no } 100}{100} \\
=\frac{177.673}{100}=1.77673
\end{gathered}
$$


Dilihat dari grafik, maka masuk zona 2

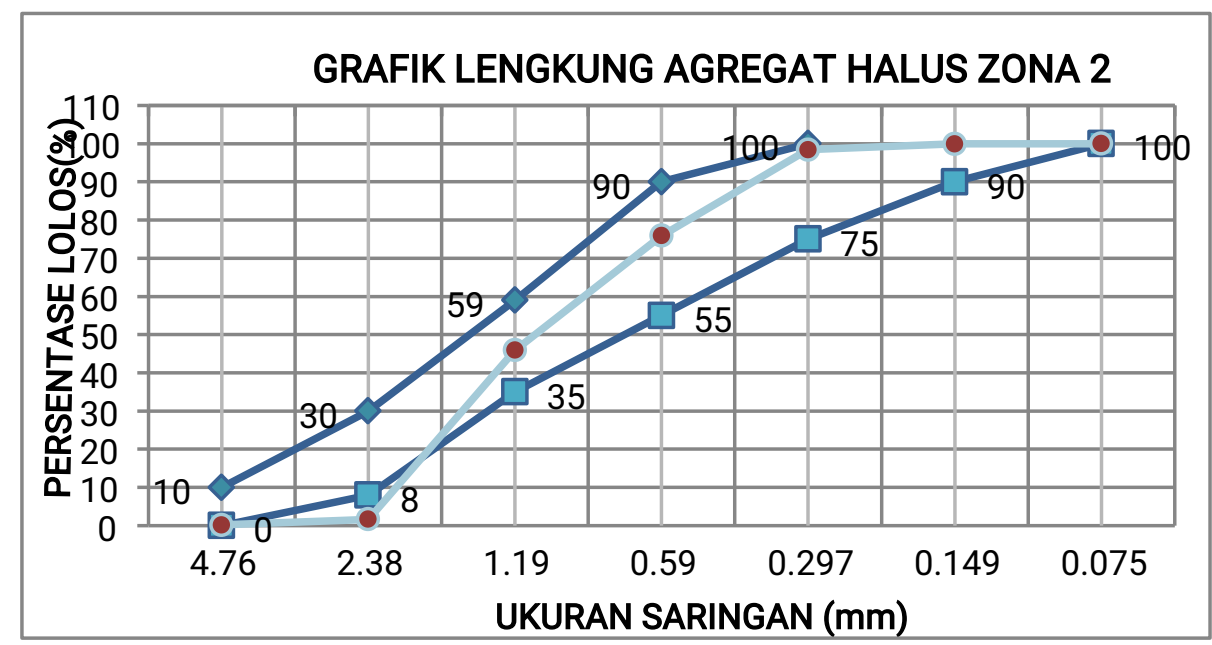

Grafik 4 Lengkung agregat halus zona 2

Kadar air agregat halus rata - rata $0.38 \%$

\section{Berat jenis dan penyerapan agregat halus}

a) Berat Jenis Curah sebesar 2.772 gram

b) Berat Jenis Kering Permukaan Jenuh sebesar 2.841

c)Berat Jenis Semu sebesar 2.978 gram

d) Penyerapan (\%)sebesar $2.501 \mathrm{gram}$

\section{Kebutuhan Bahan (mix design)}

Berdasarkan dari perhitungan kebutuhan bahan material (mix design) memerlukan :
a)Semen
$: 5.78 \mathrm{~kg}$
b)Air
$: 3.76 \mathrm{lt}$
c)Agregat halus
$: 11.29 \mathrm{~kg}$
d)Agregat kasar
$: 23.14 \mathrm{~kg}$

\section{Pengujian kuat tekan beton}

Pengujian tekan benda uji dilaksanakan setelah pencetakan benda uji,dikeringkan dalam suhu ruang selama 24 jam, lalu direndam selama 7 hari dan dikeringkan selama 24 jam

Tabel 2 Uji kuat tekan beton 3 sample

\begin{tabular}{|c|c|c|c|c|c|c|c|c|}
\hline $\begin{array}{c}\text { Nama } \\
\text { Benda } \\
\text { Uji }\end{array}$ & $\begin{array}{c}\text { Diameter } \\
\text { Benda Uji } \\
(\mathrm{mm})\end{array}$ & $\begin{array}{c}\text { Tinggai } \\
\text { Benda Uji } \\
(\mathrm{mm})\end{array}$ & $\pi$ & \begin{tabular}{|c|} 
Luas \\
Penam \\
pang \\
$\mathrm{mm}$ \\
(A)
\end{tabular} & $\begin{array}{c}\text { Beban } \\
\text { Maksimum } \\
\text { (newton) } \\
\text { (P) }\end{array}$ & $\begin{array}{c}\text { Kuat } \\
\text { Tekan } \\
\text { P/A } \\
\text { (Mpa) }\end{array}$ & \begin{tabular}{|c|} 
Kuat \\
Tekan 7 \\
Hari 65\% \\
$(\mathrm{Mpa})$
\end{tabular} & $\begin{array}{c}\text { Rata - Rata } \\
\text { Kuat Tekan } \\
\text { ( Mpa ) }\end{array}$ \\
\hline$\overline{\mathrm{A} 1}$ & 150 & 300 & 3.14 & 17662.5 & 93000 & 5.265 & 8.101 & \multirow{3}{*}{7.802} \\
\hline $\mathrm{A} 2$ & 150 & 300 & 3.14 & 17662.5 & 88900 & 5.033 & 7.743 & \\
\hline A3 & 150 & 300 & 3.14 & \begin{tabular}{|l|}
17662.5 \\
\end{tabular} & 86800 & 4.914 & 7.561 & \\
\hline B1 & 150 & 300 & 3.14 & \begin{tabular}{|l|}
17662.5 \\
\end{tabular} & 35100 & 1.987 & 3.057 & 3.208 \\
\hline
\end{tabular}


Muhamad Nasrulloh, Achendri M. Kurniawan. 2018. Perbandingan variasi agregat halus yang berasal dari gunung kelud, kali putih, dan sungai brantas terhadap kuat tekan beton. Jurnal Qua Teknika, (2018), 8 (1) : 32-41

\begin{tabular}{|l|l|l|l|l|l|l|l|l|}
\hline B2 & 150 & 300 & 3.14 & 17662.5 & 36200 & 2.050 & 3.153 & \\
\hline B3 & 150 & 300 & 3.14 & 17662.5 & 39200 & 2.219 & 3.414 & \\
\hline C1 & 150 & 300 & 3.14 & 17662.5 & 33700 & 1.908 & 2.935 & \\
\hline C2 & 150 & 300 & 3.14 & 17662.5 & 43900 & 2.485 & 3.824 & \multirow{2}{*}{3.272} \\
\hline C3 & 150 & 300 & 3.14 & 17662.5 & 35100 & 1.987 & 3.057 & \\
\hline
\end{tabular}

Setelah dilakukan uji tekan benda uji, maka kekukatan (Mpa) benda dari 9 buah benda uji dari 3 sampel agregat halus dapat dilihat pada diagram dibawah ini :

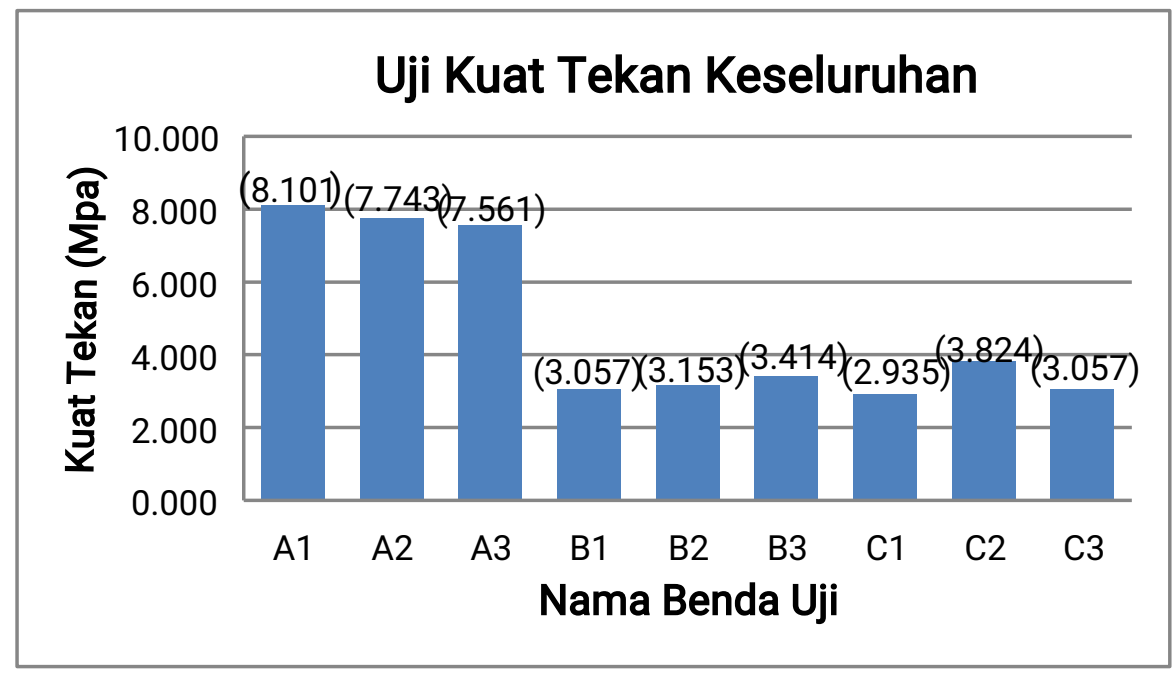

Diagram 1 Uji kuat tekan beton 3 sampel

\section{SIMPULAN}

Berdasarkan dari hasil pengujian kuat tekan beton, maka dapat disimpulkan sebagai berikut :

1) Penelitian perbedaan karakteristik Agregat halus (pasir) dari 3 lokasi berbeda di Blitar yang terdiri dari 3 sampel, memiliki kekuatan tekan yang bervariasi yaitu :

a) Sampel 1 agregat halus (pasir) gunung Kelud. Menhasilkan rata - rata uji kuat tekan beton sebesar 7,802 Mpa (tertinngi)

b) Sampel 2 agregat halus (pasir) Kali Putih menghasilkan rata - rata uji kuat tekan beton sebesar 3,208 Mpa (terendah)

c) Sampel 3 agregat halus (pasir) sungai Brantas menghasilkan rata - rata uji kuat tekan beton sebesar 3,272 Mpa

2) Agregat halus memegang peranan yang sangat penting dalam pembuatan sebuah cor beton, yang dimana pemilihan agregat halus yang baik (sesuai prosedur) akan membuat beton yang kuat saat dilakukan uji tekan terhadap benda uji |(beton) tersebut.

\section{DAFTAR PUSTAKA}

Anonym, http://asat.staff.umy.ac.id/file/2010/07/SNI-1969-2008.pdf\&sa

Anonym,https://hadaiyatullailliah.wordpress.com/2016/04/02/bahan-penyusu-beton

Anonym, https://id.wikipedia.org/wiki/Agregat

Anonym,http://share.its.ac.id/pluginfile.php/19655/mod_folder/content/0/MATERI\%203

\%20AGREGAT.pdf?forcedownload=1

Heri Suprapto hsuprapto@staff.gunadarma.ac.id/ Studi Sumber Agregat Halus dan Pengaruhnya 
Muhamad Nasrulloh, Achendri M. Kurniawan. 2018. Perbandingan variasi agregat halus yang berasal dari gunung kelud, kali putih, dan sungai brantas terhadap kuat tekan beton. Jurnal Qua Teknika, (2018), 8 (1) : 32-41

Dalam Pembuatan Beton Normal

Jumantoro,http://jumantorocivilengiinering.blogspot.co.id/2015/03/kelebihan-dankekuranganbeton.html

JunaidaWally,at10:06:00,https://junaidawally.blogspot.co.id/2013/05/karakteristik-darisifatmekanik-beton.html

Khairul Fajri, http://www.dataarsitek.com/2017/01/pengertian-agregat-jenis-danklasifikasi-KasarHalus.html Richard,http://richarddelevan.blogspot.co.id/2014/09/kekurangan-dan-kelebihanbetonuntuk-material-bangunan.html

Rony,https://ronymedia.wordpress.com/2010/04/19/bentuk-agregat-menetukan-mutubeton/, RukmanPattinjjo,https://www.academia.edu/10290688/DEFINISI_BETON_DAN_BET ON_BERTULANG

Sjafei Amri, ST., Dipl.E.Eng, Teknologi Beton A - Z, 06.42

Yohanes akhriadi,http://rumah12.blogspot.co.id/2012/12/agregat-dan persyaratanagregat.html 